\title{
Physiochemical changes associated with foliar gall formation by a psyllid insect Trioza pallida Haupt. in Mallotus philippensis Muell. Arg.
}

\author{
Ajoykumar $\mathrm{KN}^{1 *}$, Subitha $\mathrm{PP}^{2}$ \\ Department of Botany, Nirmalagiri College, Kannur, Kerala, India, $670701^{1 \& 2}$ \\ Email: knajoykumar@gmail.com
}

\begin{abstract}
Gall is acting like a metabolic sink and hence it is expected that there is wide variation in the distribution of metabolites and metabolic activity of the host plant. Since leaf is the site of gall infection the changes may be noticeable in leaf when compared to other parts of the plant. In this study, efforts has been taken to estimate photosynthetic pigments, total soluble sugar, total carbohydrates and starch content of the galled and ungalled leaf of Mallotus philippensis which helps to comprehend the carbohydrate metabolism of the plant. Total protein content, total free amino acid content, proline content, activity of amylase and invertase enzymes has also attempted in the present investigation. Total chlorophyll tends to decrease in the galled tissue where as significant increase was recorded in the carotenoid content of galled leaves. The metabolites like protein, aminoacid, starch and carbohydrates tend to increase significantly in the galled leaves as compared to the control leaves. Similarly increased accumulation of osmolytes like proline and soluble sugar was also recorded in accordance with the gall formation. These results indicate that, gall forming insects has rescheduled the metabolic pathways of the host plants, in such a way that the gall forming tissue can act as a metabolic sink there by aiding nutrition to the insects. In addition, the increased accumulation of osmolytes indicates the presence of well defined antioxidant machinery operating in the plant under biotic stress.
\end{abstract}

Index Terms- carbohydrate, gall, Mallotus philippensis, osmolytes, proline.

\section{INTRODUCTION}

A gall is an abnormal growth or tumour on plant tissue mainly caused by the attack of an insect, bacteria or fungus and it influences the growth and development of plants. It is interesting to note that the association between the organism that induce gall and their host plant is more intimate than any kind of plant-pathogen interactions (Fernandez et al. 1990; Singh and Sharma 2008). Despite their wide distribution, galls usually do not have a large harmful effect on their hosts. These pathogens are highly concentrated on gall formation in plants and many of them may stunt the plant growth only on that particular part on which it grows. However, too many galls on one host will harm the plant. It is an evolutionary feature that the galls do not totally destroy its hosts because of the shelter and nutrients provided by the plants for them over a long period. If the host dies, the insects, bacteria or fungus living within it will also die.

Galls are not much hazardous to plants but they may influence the physiology and metabolic activities and thereby reducing the productivity of crops. Since most of the galls are formed in wild varieties of plants, the productivity aspects of gall infected plants are not much studied. Some organisms induce gall specifically in one host species, while the others may form in a few closely related species within a genus. The mechanisms behind this gall formation by the attack of pathogens like insects, bacteria, fungi, etc. remain largely unknown till date. The gall producing organisms may switch on certain developmental pathways so as to modify the morphology of plants by isolating gene expression. The gall thus produced will develop a well defined nutritional system (Raman 2007).

Among different type of galls, the most widely distributed galls are insects induced galls and are believed to be the most intimate and specific with the host. Till date about 15000 insects have been identified as potential candidates for inducing gall. Presence of insects induces the plant to form a protective gall with full of nutritive tissue which can vary in sizes from microscopic to wide-ranges. The insect also produce various chemicals and some proteolytic enzymes that influence the formation of galls (Purcell et al. 2017).

The present work aim to reveal the biochemical changes during insect induced foliar galls formation of Mallottus philippensis Muell. Arg. (Euphorbiaceae) by a Psyllid insect Trioza pallida Haupt. Mallotus philippensis is a perennial shrub or small tree widely distributed in the tropical and subtropical regions of the world. The extensive 


\section{E-ISSN: 2321-9637 \\ Available online at www.ijrat.org}

pharmacological applications of $M$. philippensis have been reported earlier and are considered largely as a traditional medicine in several countries including India. It is a rich source of different natural compounds including phenols, diterpenoids, steroids, flavonoids, cardenolides, triterpenoids, coumarins, etc. and is used mainly in ayurveda (Ganwar et al. 2014).

Moreover the plant extract is having certain biological activities such as antimicrobial, antioxidant, antiviral, anticancerous, cytotoxicity, antiinflammatory and possess immune-regulatory function also (Ganwar et al. 2014). Since, it is a valuable source of several medicinally important natural molecules, and offer a great deal in the future as modern medicine, the study of gall infection of $M$. philippensis and the change in associated metabolite profile is attaining significance.

\section{METHODOLOGY \\ 2.1 Plant material}

Gall leaf samples of $M$. philippensis (induced by an insect- Trioza pallida) were collected from different localities near Nirmalagiri College, Kuthuparamba, Kerala. Ungalled leaf of $M$. philippensis served as control (Fig. 1). Preferably, leaves of the same size and of same developmental stages were collected. All analyses were done with fresh leaf samples immediately after harvesting.

\subsection{Physiological parameters}

2.2.1 Photosynthetic pigments

Estimation of chlorophyll and carotenoid contents were done according to the method of Arnon (1949). Fresh samples were crushed using 80\% acetone and the homogenate was centrifuged at 5000 $\mathrm{rpm}$ for $10 \mathrm{~min}$ at $4^{\circ} \mathrm{C}$. The absorbance was read at $663,646,750$ and $470 \mathrm{~nm}$ against blank reagent $(80 \%$ acetone).

\subsection{Biochemical parameters}

\subsubsection{Metabolites}

2.3.1.1 Total protein

Protein concentrations in the leaf extract was determined following the method of Lowry et al. (1951) using defatted Bovine serum albumin (fraction V) as a standard.

\subsubsection{Total free amino acids}

Total amino acid estimation was done by the method of Moore and Stein (1948). Total free amino acids were calculated from a standard curve 320 prepared with glycine.

\subsubsection{Starch}

The starch content of leaf samples was determined using the method of Pucher et al. (1948). Soluble starch was used as the standard.
The estimation of total carbohydrate was carried out by the method of Hedge and Hofreiter (1962) using glucose as standard.

\subsubsection{Osmolytes}

\subsubsection{Proline}

Free proline content was extracted from fresh samples using 3\% sulfosalicylic acid and estimated following the method of Bates et al. (1973). L-proline was used as standard.

\subsubsection{Total soluble sugar}

Total soluble sugar was extracted from fresh samples using $80 \%$ ethanol and estimated following the method of Dubois et al. (1956). Standard curve was plotted using D-Glucose as standard.

2.3.3 Enzymes

\subsubsection{Invertase (E.C.3.2.1.26)}

Invertase activity was determined indirectly by measuring the production of reducing sugar from sucrose according the method described by Miller (1959).

\subsubsection{2 $\alpha$-Amylase (E.C.3.2.1.1)}

$\alpha$ - Amylase activity was determined by measuring the production of maltose and other reducing sugars from amylopectin of amylase using 3, 5-dinitrosalicyclic acid (DNSA). The method described by Bernfeld (1955) was followed.

\subsection{Statistical analyses}

Statistical analysis of the results was carried out according to Duncan's multiple range tests at 5\% probability level. Data were subjected to one-way ANOVA using the SPSS software 16.0. The data represent mean \pm standard error.

\section{RESULTS}

\subsection{Physiological parameters}

\subsubsection{Photosynthetic pigments}

In the control leaves, total chlorophyll content tends to increase from younger leaves to mature leaves and there after it reduced. However, in the case of galled leaves total chlorophyll content tend to increase from younger stage to senescing stage. Compared to the control leaves, galled leaves recorded significant reduction of about 3 fold, 6 fold and 2 fold in the younger, mature and senescing stages of leaves respectively. $\mathrm{Chl} \mathrm{a} / \mathrm{b}$, which is now widely used as an indicator of stress, increased in the younger and mature leaves of control as well as galled leaves, i.e., compared to control, about 24 and $123 \%$ increase was observed in the young and mature leaves of galled plants. But, a decrease of about $38 \%$ was observed in the $\mathrm{Chl} \mathrm{a} / \mathrm{b}$ ratio for the galled senescing leaves as compared to the control senescing leaves. Carotenoid content also exhibited a significant increase in the control as well as galled leaves. An increase of about 70,39 and $206 \%$ was recorded in the galled leaf over the control leaves in the young, mature and senescing stage respectively (Table 1). 


\author{
E-ISSN: 2321-9637 \\ Available online at www.ijrat.org
}

\subsection{Biochemical parameters}

3.2.1 Metabolites

3.2.1.1 Total protein

In general, protein content tends to increase in the galled leaf as compared to the control leaves in all stages of development (young, mature and senescing leaves). An increase of about 43, 40 and $55 \%$ was recorded in the young, mature and senescing galled leaves respectively over the control leaves (Table 2).

\subsubsection{Total free amino acids}

Similar to total protein, total free aminoacid content also increased significantly in the galled leaves over the control leaves. About 77, 150 and $224 \%$ increase in the total free aminoacid content was recorded in the young, mature and senescing galled leaves respectively over the control leaves (Table 2).

\subsubsection{Starch}

Compared to the total protein and amino acid content, the enhancement in the accumulation of starch content was much lower in the young and mature galled leaves, about 7 and $25 \%$ increase only as compared to the control leaves. But in the case of senescing galled leaves, about $64 \%$ increase of starch content was observed over the control senescing leaves (Table 2).

\subsubsection{Total carbohydrates}

Control leaves of $M$. philippensis recorded a gradual increase of total carbohydrate content from young to senescing stages of leaf development. Total carbohydrate content of the galled leaves tend to increase significantly in all stages of leaf as compared to the control leaves, i.e., young (33\%), mature (50\%) and senescing $(5 \%)$ leaves with respect to the control (Table 2).

\subsubsection{Osmolytes}

\subsubsection{Proline}

In general, remarkable enhancement of proline content was recorded for the galled leaves during all stages of leaf development. As compared to the control leaves, about 4,3 and 9 fold increase of proline content was registered in the young, mature and senescing galled leaves of $M$. philippensis respectively (Table 2 ).

\subsubsection{Total soluble sugar}

Like all other metabolites, total soluble sugar content also recorded an enhanced profile in the galled leaves as compared to the control leaves. An increase of about 17,42 and $21 \%$ was monitored in the young, mature and senescing galled leaves respectively over the control leaves (Table 2).

3.2.3 Enzymes

\subsubsection{Invertase}

Activity of invertase enzyme increased significantly in the young and mature galled leaves of M. philippensis, i.e., about 53 and $80 \%$ increase respectively over the control leaves. However, in the senescing galled leaf a decrease of about $23 \%$ was recorded over the control senescing leaves (Fig. 2a). 3.2.3.2 Amylase

Compared to the activity of invertase, marked enhancement was recorded for the activity of amylase in the galled leaves of $M$. philippensis. Significant increase of about 76, 13 and $124 \%$ was recorded in the young, mature and senescing galled leaves respectively over the control leaves (Fig. 2b).

\section{DISCUSSION}

The gall system stimulates specialized nutritional system and have distinctive "nutritive tissues" upon which the insect feeds and may contain elevated nutrients (Schonrogge et al. 2000). It has been discussed that some insects have the ability to become phloem sinks within the plant, channeling some of the plant's nutrients directly to the growing larvae. The insect take advantage of source-sink relationship in the plant and thus become a competitor with the plant for resources. During gall formation, the insect switches the growth and differentiation process of plants which enable them to act as a sink of nutritive substances. These substances were reallocated from the host plants by active mobilization from cells adjacent of the gall.

4.1 Physiological parameters

The present attempt was to explore the physiological and biochemical changes in the leaves of M. philippenesis associated with gall formation. In the present study, significant decline in the total chlorophyll content (both chlorophyll a and b) were recorded in the galled leaf as compared with that of control leaves. Further, it is noticed that chlorophyll content of gall tissues showed significant decrease as growth progressed. This loss of chlorophyll is attributes to the de-colorization of the leaf where the gall is formed. Similar observation was also obtained in the leaves of other plants like Ficus (Moghe 1980, Albert et al. 2011). The low chlorophyll content in the galled leaf might also be due to the loss of palisade tissues, disintegration of chloroplast and modifications of spongy mesophyll tissue as the insect inhabit the leaf (Moghe 1980). Reduction in photosynthesis by the impact of an invasive painted bug ON its host BRASSICA OLERACEA var botrytis was studied recently by Guarino et al. (2017).

The increased carotenoid content triggered by the gall in $M$. philippensis leaves, protects the thylakoid membrane from ROS-mediated peroxidative damage and thereby preventing loss of thylakoid proteins function. Carotenoids are lipid soluble pigments functioning as antioxidants to quench or scavenge the free radicals and thus prevent the damage of cell (Taiz and Zeiger 2002; Gill and Tuteja 2011). In addition to their antioxidant property, they assist the PSI assembly and maintain the stability of light harvesting proteins as well as thylakoid 


\section{E-ISSN: 2321-9637 \\ Available online at www.ijrat.org}

membrane thereby providing integrity to the photosynthetic machinery (Niyogi et al. 2001; Pandey et al. 2009).

\subsection{Biochemical parameters}

The increased protein content in galled region point out the fact that directed localization of proteins happens in the gall tissues as compared to healthy tissue. The enhanced protein content observed in the gall tissue correlates with the observations of Mahalingam et al. (1999). He observed the presence of certain stress proteins in the gall tissue of Populus nigra. These results were also in line with Arora and Patni (2001) and El- akkad (2004). Thus, the obvious increase in protein content of the galled leaf of the present work might be due to the accumulation of stress proteins. It has been reported by many researchers that the gall region is a metabolic sink and the galled leaf showed a significant increase in the protein content when compared to normal leaf (D'Souza and Ravishankar 2014).

Proteins that block the action of certain proteolytic enzymes secreted by the herbivores have been isolated from a wide variety of plants including legumes, tomatoes, etc. (Rashid et al. 2012). These proteins are generally grouped in a class namely proteinase inhibitors, and are accumulated in plants as a response to insect feeding. On the other hand, the increase in protein content may be due to the presence of some proteolytic enzymes produced by the insects present in the galled leaf as suggested by Schonrogge et al. (2000). Since the accumulation of these proteins are not normally found in other parts of leaf or plants, it is a clear indication of how the larva are reprogramming plant development so as to develop gall (Harper et al. 2004).

Galled leaves of $M$. philippensis also recorded an increase in total free amino acid content and are in consensus with the earlier studies conducted by Chauhan et al. (1984) in Boerhaavia diffusa. The amino acid profile of both healthy and infested leaves of $B$. diffusa clearly indicate that healthy leaves possess nine amino acids where as twelve were recorded in the gall leaves. The additional aminoacids include alanine, threonine and tyrosine. The gall tissues also exhibited a marked increase in the quantities of cystine, lysine and phenylalanine as compared to those of control leaf. According to Miles and Lloyd (1967), this increased amino acids in gall tissues might be the break down product of proteins by the enzyme protease secreted by the insects. The present study also observed similar enhanced profile of aminoacid content in the galled tissue and it indicates a higher metabolic activity in the galled region of the leaf as indicated by Golan et al. (2017).

Amylase activity recorded was significantly higher in gall tissue as compared to normal healthy tissue. Starch content and $\alpha$-amylase activity has seen to be go hand in hand in the present study. The higher the starch content, the higher is the $\alpha$-amylase activity. Similarly, carbohydrates may also accumulate due to the activities of other enzymes associated with the metabolism (Shekhawat 1980; Rao 1989).

Proline metabolism has been extensively studied by several researchers especially in connection with drought and other abiotic stresses. Additionally, there is increasing evidence that proline is also involved in biotic stress especially plant pathogen interactions and is dealt with programmed cell death and development (Gibon et al. 2000). Galled tissue recorded a much high profile of proline as compared to the control leaves indicating a stressed condition caused by the attack of insect in the galled tissue. Generally proline is known to accumulate under stressful environment and offer a potential defence mechanism so as to protect from invaders (biotic stress) or other stress factors (abiotic stress).

Proline is a stress induced amino acid and estimation of proline may be used as an indication of the gravity of the insect induced gall stress in Mallotus. During gall formation proline content tend to be increased significantly in the leaves of $M$. philippensis. This is in consensus with the studies conducted in Alstonia scholaris where an enhanced level of proline content was registered in the galled leaves as compared to the ungalled leaves. Increase in proline content was also recorded in the galled leaves of Populus plants by El-Akkad (2004). The determination of proline is therefore very useful to assess the physiological status and more generally to understand stress tolerance in plants.

Proline is an excellent compatible solute which protects the structure of functional proteins against denaturation, stabilizes cell membranes by interacting with phospholipids, functions as a free radical scavenger, or serves as an energy and nitrogen source (Seyyednejad et al. 2009). The contribution to osmotic adjustment and tolerance of plants exposed to unfavorable environmental conditions is cited in many literatures (Gibon et al. 2000). Stress-regulated changes in proline synthesis and degradation may also affect the signalling of other genes, ensuring that the response to stress is appropriate to the prevailing environmental conditions (Seyyednejad et al. 2009).

In the present investigation, it has been identified that there is a higher amount of total sugar in the young galled leaf itself. The increase in the accumulation of total sugar can be explained with the increase in the rate of invertase activity of the galled leaf. Singh and Sharma (2008) have also reported that total soluble sugar, starch and $\alpha$-amylase activity increased in leaves with galls. They have recorded a high invertase activity in the gall tissues, which would have increased the total sugar content in the same. The close relationship between sink strength and invertase activity in normal plant tissues and gall tissues have 


\section{E-ISSN: 2321-9637 \\ Available online at www.ijrat.org}

been reported earlier (Allison and Schultz 2005). The result of the present study showed an increased activity of invertase and is a direct means by which insect galls become nutritional sinks.

Galls are known to act as excellent sinks rich in plant nutrient assimilates (Larson and Whitham 1997), and presence of increased soluble invertase are associated with the establishment of sink (Patrick 1990). Sucrose is one of the most abundant natural products in plants and play vital role in plant life. A major part of the organic carbon accumulated through photosynthesis is channeled into the synthesis of sucrose. As the major transportable form of sugar in the plant, sucrose is delivered from the photosynthetic tissue to all plant organs, to serve as the source of organic carbons as metabolic fuel for production of energy. So once infected, inside the host tissue these organisms reprogram the host metabolism and utilize the excess sugars present in the plant for their growth and sustenance. This accumulation may involve the translocation of soluble sugars from the neighboring healthy tissues to the physiological sinks created by the insects.

\section{CONCLUSION}

The present research indicated a greater elevation of proteins, total free amino acids, proline, total soluble sugar, starch and total carbohydrate in gall tissues as compared to the normal leaves. This corroborates the hypothesis that galls are known to act as sinks for plant nutrients, i.e., the results supports the view of nutritional hypothesis that the gall provides a superior food source to the insect. Study of the activity of invertase and amylase further helped in the understanding of carbohydrate metabolism and sucrose transport to various sinks of the plant, and also the efficacy of the utilization of photosynthetic products. Our physiochemical characterization of galls on $M$. philippensis leaves indicates that the larvae of the insect reorganize the developmental pathway of the host, so as to benefit its own nutritional status and there by its growth and development. In addition, plants also develop well defined antioxidant machinery against the invading pathogen as indicated by the increased accumulation of osmolytes like proline and sugars.

\section{REFERENCES}

[1] Albert S, Padhiar A, Gandhi D, Nityanand P (2011) Morphological, anatomical and biochemical studies on the foliar galls of Alstonia scholaris (Apocynaceae). Rev Bras Bot 34:3.

[2] Allison SD, Scholtz JC (2005) Biochemical responses of chestnut oak to a galling cynipid. J Chem Ecol 31:151-166

[3] Arnon DJ (1949) Copper enzymes in isolated chloroplasts. Plant Physiol 24:1-25
[4] Arora DK, Patni V (2001) Localisation of metabolites and enzymes in insect induced rachis gall and normal tissues of Prospis cineraria (Linn.) Druce. J Phytol Res 14: 179-81

[5] Bates LS, Waldren RP, Teare ID (1973) Rapid determination of free proline for water stress studies. Plant Soil 39:205-208

[6] Bernfeld P (1955) Alpha and Beta amylases. Meth Enzym 1:149-158

[7] Chauhan SVS, Dhingra PK, Kinoshita T (1984) Some biochemical alterations in insect induced leaf galls of Boerhaavia diffusa L. J Fac Agric Hokkadio University (Japan) 61:1371-1376

[8] D’Souza MR, Ravishankar BE (2014) Nutritional sink formation in galls of Ficus glomerata Roxb. (Moraceae) by the insect Pauropsylla depressa (Psyllidae, Hemiptera). Trop Ecol 55:129-136

[9] Dubois M, Gilles KA, Hamilton JK, Rebers PA, Smith F (1956) Colourimetric determination of sugars and related substances. Analyt Chem 26:351-356

[10] El-Akkad SS (2004) Biochemical changes induced in Populus nigra leaves by galling aphids Pemphigous populi. Int J Agri Biol 6:659-664

[11] Fernandez GW, Carneiro MAA, Marydossantos IR (1990) Gall-inducing insects: from anatomy to biodiversity. In: Panizzi AR, Parra JRP (eds) Insect bioecology and nutrition for integrated pest management. CRC Press, Taylor \& Francis, pp 369-395

[12] Ganwar M, Goel R, GopalNath K (2014) Mallotus philippensis. Muell. Arg. (Euphorbiaceae). Ethnopharmocology and phytochemistry review. Biomed Res Int 2014:113

[13] Gibon Y, Sulpice R, Larher F (2000) Proline accumulation in canola leaf discs subjected to osmotic stress is related to the loss of chlorophylls and to the decrease of mitochondrial activity. Physiol Plant 110:469-76

[14] Gill SS, Tuteja N (2011) Cadmium stress tolerance in crop plants. Plant Signal Behav 6:215-222

[15] Golan K, Sempruch C, Górska-Drabik E, Czerniewicz P, Łagowska B, Kot I, Kmieć K, Magierowicz K, Leszczyński B (2017) Accumulation of amino acids and phenolic compounds in biochemical plant responses to feeding of two different herbivorous arthropod pests. Arthropod-Plant Interact 11:675-682

[16] Guarino S, Peri E, Colazza S, Luchi N, Michelozzi M, Loreto F (2017) Impact of the invasive painted bug BAGRADA HILARIS on physiological traits of its host BRASSICA OLERACEA var botrytis. Arthropod-Plant Interact 11:649-658

[17] Harper LJ, Schonrogge K, Lim KY, Francis P, Lichtenstein CP (2004) Cynipid galls: insect- 


\section{Available online at www.ijrat.org}

induced modifications of plant development create novel plant organs. _Plant Cell Environ 27:327-335

[18] Hedge JE, Hofreiter BT (1962) Carbohydrate chemistry In: Whistler RL, BeMiller JN (eds) Methods in carbohydrate chemistry. Academic Press, New York, pp 420

[19] Larson KC, Whitham TG (1997) Competition between plant galls and natural plant sinks, Plant architecture affects resistance to galling. Oecologia 88:575-582

[20] Lowry OH, Rosebrough NJ, Farr AL, Randall RJ (1951) Protein and measurement with phenol reagent. J Biol Chem 193:265-275

[21] Mahalingam R, Wang G, Knap HT (1999) Polygalacturonase and polygalacturonase inhibitor protein: Gene isolation and transcription in Glycine max-Heterodera glycines interactions. Mol Plant Microbe Interact 12:490-498

[22] Miles PW, Lloyd J (1967) Synthesis of a plant hormone by the salivary apparatus of plant sucking bugs. Nature (London) 203:801-802

[23] Moghe M (1980) Studies on the insect gall of Ficus racemosa Linn. Ph.D. Thesis, The Maharaja Sayajirao University, Vadodara

[24] Moore S, Stein WH (1948) Photometric ninhydrin method for use in chromatography of amino acids. J Biol Chem 176:367-388

[25] Miller GL (1959) Use of dinitosalicylic acid reagent for determination of reducing sugar. Anal Chem 31:426-428

[26] Niyogi KK, Shih C, Soon CW, Pogson BJ, DellaPenna D, Björkman O (2001) Photoprotection in a zeaxanthin- and luteindeficient double mutant of Arabidopsis. Photosynth Res 67:139-45

[27] Pandey S, Nelson DC, Assmann SM (2009) Two novel GPCR-type G proteins are abscisic acid receptors in ARABIDOPSIS. CELL 10:136-148

[28] Patrick JW (1990) Sieve element unloading, cellular pathway, mechanism, and control, photosynthesis and carbohydrate synthesis in pearl millet leaves. Indian Phytopath 28:565-566
[29] Pucher GW, Leaven WCS, Vickery HB (1948) Determination of starch in plant tissues. Anna Chem 20:850-853

[30] Purcell MF, Thornhill AH, Wallenius TC, Yeates DK, Rowell DM (2017) Plant host relationships of three lineages of the gall-inducing fly FERGUSONINA malloch (Diptera: Fergusoninidae) on EUCALYPTUS L'Hérit. Arthropod-Plant Interact https://doi.org/10.1007/s11829-017-9561-1

[31] Raman A (2007) Insect-induced plant galls of India: unresolved questions. Curr Sci 92:748-757

[32] Rao DV (1989) In vivo and in vitro studies of green ear disease of pearl millet (Bajra) caused by Sclerospora graminicola (Sacc.) Schroet with special reference to host parasite interaction, biochemistry and control. Ph.D. Thesis, University of Rajasthan, Jaipur, India

[33] Rashid A, Paulraj W, Gabriel M, Tariq A, Ahad BA, Hussain B, Ignacimuthu, Savrimuthu, Sharma H (2012) Mechanisms of plant defense against insect herbivores. Plant Signal Behav 7:1306-1320

[34] Schonrogge K, Harper LJ, Lichtenstein CP (2000) The protein content of tissues in cynipid galls (Hymenoptera: Cynipidae): Similarities between cynipid galls and seeds. Plant Cell Environ 23:215-222

[35] Seyyednejad SM, Niknejad M, Yusefi M (2009) The effect of air pollution on some morphological and biochemical factors of Callistemon citrinus in petrochemical zone in South of Iran. Asian J Plant Sci 8:562 -565

[36] Shekhawat NS (1980) Studies on the nature of abnormal growth during pathogenesis in vivo and in vitro state with special reference to green ear in pearl millet. Ph. D. Thesis, J.N.V. University, Jodhpur, India

[37] Singh MK, Sharma SL (2008) Quantitative estimation of some metabolites and enzymes in insect induced leaf gall of Mangifera indica. Asian J Exp Sci 22:343-346

[38] Taiz L, Zeiger E (2002) Plant physiology, 3rd Edition. Sinauer Assoc., Sunderland.

Table 1 Changes in the photosynthetic pigment content of Mallotus philippensis Muell. Arg. at three developmental stages of leaves during gall formation. Different alphabetical letters indicate statistically different means at $p \geq 0.05$

\begin{tabular}{l|ccc|ccc}
\hline $\begin{array}{c}\text { Parameters } \\
(\mathbf{m g} / \mathbf{g} \text { DW) }\end{array}$ & Young & $\begin{array}{c}\text { Control leaf } \\
\text { Mature }\end{array}$ & Senescing & Young & $\begin{array}{c}\text { Galled leaf } \\
\text { Mature }\end{array}$ & Senescing \\
\hline Chl a & $3.01 \pm 0.15^{\mathrm{b}}$ & $3.87 \pm 0.18^{\mathrm{a}}$ & $1.68 \pm 0.07^{\mathrm{c}}$ & $1.18 \pm 0.04^{\mathrm{a}}$ & $0.74 \pm 0.02^{\mathrm{b}}$ & $0.66 \pm 0.03^{\mathrm{c}}$ \\
$\mathrm{Chl} \mathrm{b}$ & $1.42 \pm 0.06^{\mathrm{a}}$ & $1.52 \pm 0.06^{\mathrm{a}}$ & $1.02 \pm 0.04^{\mathrm{b}}$ & $0.45 \pm 0.02^{\mathrm{b}}$ & $0.13 \pm 0.001^{\mathrm{c}}$ & $0.64 \pm 0.03^{\mathrm{a}}$ \\
Chl a/b & $2.12 \pm 0.11^{\mathrm{b}}$ & $2.55 \pm 0.11^{\mathrm{a}}$ & $1.65 \pm 0.08^{\mathrm{c}}$ & $2.62 \pm 0.12^{\mathrm{b}}$ & $5.69 \pm 0.21^{\mathrm{a}}$ & $1.03 \pm 0.04^{\mathrm{c}}$ \\
Total Chl & $4.43 \pm 0.21^{\mathrm{b}}$ & $5.39 \pm 0.25^{\mathrm{a}}$ & $2.7 \pm 0.12^{\mathrm{c}}$ & $1.63 \pm 0.07^{\mathrm{a}}$ & $0.87 \pm 0.03^{\mathrm{c}}$ & $1.30 \pm 0.05^{\mathrm{b}}$ \\
Carotenoid & $0.23 \pm 0.01^{\mathrm{c}}$ & $0.38 \pm 0.02^{\mathrm{a}}$ & $0.31 \pm 0.01^{\mathrm{b}}$ & $0.39 \pm 0.01^{\mathrm{c}}$ & $0.53 \pm 0.01^{\mathrm{b}}$ & $0.95 \pm 0.04^{\mathrm{a}}$ \\
\hline
\end{tabular}


International Journal of Research in Advent Technology, Vol.7, No.2, February 2019 E-ISSN: 2321-9637

\section{Available online at www.ijrat.org}

Table 2 Changes in the metabolite profile of Mallotus philippensis Muell. Arg. at three developmental stages of leaves during gall formation. Different alphabetical letters indicate statistically different means at $p \geq 0.05$

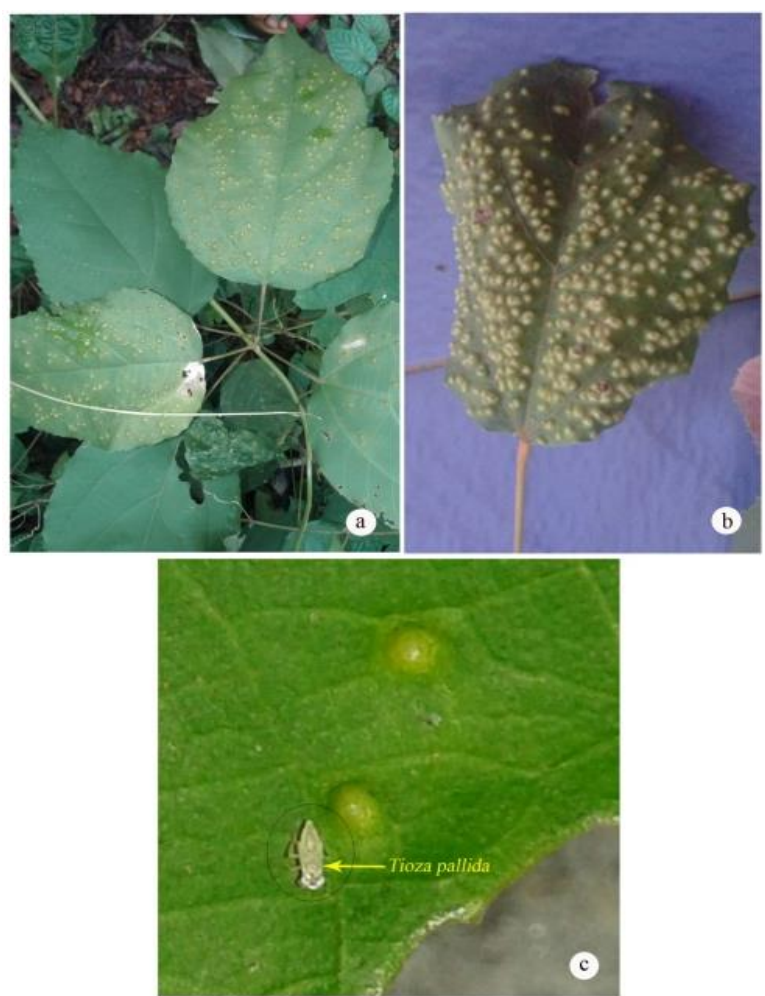

Fig 1 Gall formation in Mallotus philippensis Muell. Arg. under natural conditions

a) Habit of $M$. philippensis

b) Mature leaves of $M$. philippensis with gall

c) Gall forming insect- Trioza pallida Haupt, nom. praeocc. in the leaves of M. philippensis

\begin{tabular}{l|ccc|ccc}
\hline \multicolumn{1}{c|}{$\begin{array}{c}\text { Parameters } \\
(\mathrm{mg} / \mathrm{g} D W)\end{array}$} & Young & $\begin{array}{c}\text { Control leaf } \\
\text { Mature }\end{array}$ & Senescing & Young & Galled leaf \\
Mature & Senescing \\
\hline Total protein & $87.24 \pm 3.87^{\mathrm{b}}$ & $99.98 \pm 4.1^{\mathrm{a}}$ & $89.89 \pm 3.81^{\mathrm{b}}$ & $124.54 \pm 5.12^{\mathrm{b}}$ & $140.28 \pm 6.24^{\mathrm{a}}$ & $139.72 \pm 5.21^{\mathrm{a}}$ \\
Free amino acid & $5.47 \pm 0.18^{\mathrm{b}}$ & $6.82 \pm 0.31^{\mathrm{a}}$ & $5.09 \pm 0.21^{\mathrm{b}}$ & $9.70 \pm 0.38^{\mathrm{b}}$ & $17.08 \pm 0.72^{\mathrm{a}}$ & $16.49 \pm 0.72^{\mathrm{a}}$ \\
Starch & $68.5 \pm 2.52^{\mathrm{b}}$ & $85.05 \pm 3.96^{\mathrm{a}}$ & $60.47 \pm 2.81^{\mathrm{c}}$ & $73.32 \pm 2.84^{\mathrm{b}}$ & $106.5 \pm 4.72^{\mathrm{a}}$ & $99.17 \pm 3.52^{\mathrm{a}}$ \\
Total carbohydrates & $11.95 \pm 0.48^{\mathrm{b}}$ & $12.85 \pm 0.57^{\mathrm{b}}$ & $14.87 \pm 0.63^{\mathrm{a}}$ & $15.95 \pm 0.69^{\mathrm{b}}$ & $19.33 \pm 0.81^{\mathrm{a}}$ & $15.66 \pm 0.67^{\mathrm{b}}$ \\
Proline & $0.38 \pm 0.01^{\mathrm{b}}$ & $1.05 \pm 0.04^{\mathrm{a}}$ & $0.25 \pm 0.01^{\mathrm{c}}$ & $1.56 \pm 0.02^{\mathrm{c}}$ & $3.02 \pm 0.11^{\mathrm{a}}$ & $2.34 \pm 0.11^{\mathrm{b}}$ \\
Soluble sugar & $87.04 \pm 3.25^{\mathrm{a}}$ & $74.8 \pm 3.51^{\mathrm{b}}$ & $69.28 \pm 3.12^{\mathrm{b}}$ & $101.88 \pm 4.32^{\mathrm{a}}$ & $106.4 \pm 4.21^{\mathrm{a}}$ & $84.08 \pm 3.92^{\mathrm{b}}$ \\
\hline
\end{tabular}


International Journal of Research in Advent Technology, Vol.7, No.2, February 2019

E-ISSN: 2321-9637

Available online at www.ijrat.org
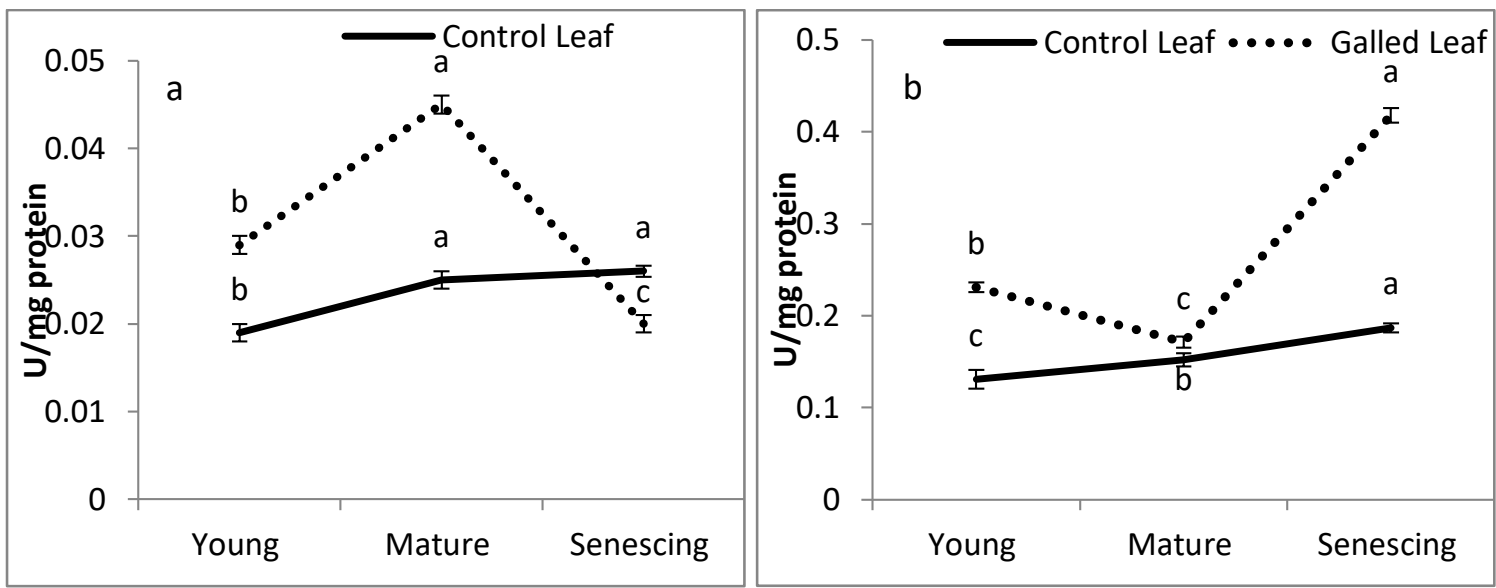

Fig. 2 Changes in the activities of invertase and amylase enzymes of Mallotus philippensis Muell. Arg. at three developmental stages of leaves during gall formation. Different alphabetical letters indicate statistically different means at $\mathrm{p} \geq 0.05$ a-invertase, $b$-amylase 